\title{
A Cognitive Stylistic Analysis of Catharsis Used by Husseini Preachers
}

DOI: https://doi.org/10.47175/rielsj.v2i4.331

\author{
| Basim Jubair Kadhim ${ }^{1, *}$ \\ 1,2Department of English, \\ College of Arts, Al-Sadiq \\ University \\ ${ }^{1}$ basimjbear@sadiq.edu.iq \\ ${ }^{2}$ mujtaba.mohammedali@sadiq \\ .edu.iq
}

\section{Mujtaba Mohammedali Yahya Al-Hilo² |}

\begin{abstract}
This study deals with catharsis as a cognitive stylistic device used to expel fear and anxiety for the sake of changing the audience toward better by preachers in Husseini discourse - Hussein is a grand Shiite Muslim leader. It aims to explicate the exploitation of catharsis by Husseini preachers and the conceptualization of such phenomenon by the audience. The study adapts the emotion model developed by Kovecses (2000); five stages are utilized: cause of emotion, emotion, control, loss of control and behavioral response. Twenty Husseini sermons are analyzed according to the stages of the model. Consequently, the study has come up with considerable conclusions. Chief among them are: Husseini preachers pragmatically use prosodic features to convey catharsis. Further conclusion is that catharsis is utilized by Husseini preachers as a strategy to teach the audience all the objectives of the Husseini revolution and to connect the objectives to this age for the sake of reform, using the fear that can modulate the human behavior.

KEYWORDS

Catharsis; Imam Hussein; Cognitive Stylistics; Husseini Preachers; Husseini Discourse
\end{abstract}

\section{INTRODUCTION}

Catharsis is an everlasting old term which is differently introduced by different fields and domains of knowledge, though it implies the same at the level of emotional effects. It is used in literature, Aristotle in poetics, then it is moved to be used in psychology, sociology, therapy, and other relative areas. Normally, catharsis is dealt with from the literary, philosophical, and thematic point of view. This paper addresses the linguistic aspects of catharsis, i.e. the stylistic cognitive manifestation of catharsis as used by Husseini preachers. It is used by Husseini preachers as a general strategy to evoke the audience feel in a way that touches their emotions and takes them to the heist levels of grief, fear, and compassion. The Husseini preacher has certain mechanisms to convey such a concept. This paper tries to shed light on the linguistic strategies and realizations that are used by Husseini preachers to lead the audience to the stage of catharsis. In other words, how catharsis is manifested through the linguistic and paralinguistic factors.

The present study aims to explore the conceptualization of linguistic forms and structures used by Husseini preachers to convey catharsis, in addition to the implications of the phenomenon in question. In this sense, it measures the power of using catharsis to affect the audience and teach them the Husseini principles and values that the preacher are after.

Giving a brief account on poetic, philosophical and linguistic levels of catharsis; the focus is on the linguistic level and its use as a stylistic device. As an emerging genre under 
linguistic studies, Husseini discourse is introduced in terms of the preaching sermons and literature review regarding the Husseini cause. Putting all these together, a model is to be adopted to stylistically analyze catharsis.

\section{LITERATURE REVIEW}

\section{Catharsis}

According to the Oxford Dictionary Reference, catharsis is a process used to relief from all the emotions that are repressing and affecting. It is based on the treatment of Aristotle under the notion of release which is used in drama (www.oxfordreference.com). Focusing on the function used by this phenomenon, catharsis is defined by Britannica Encyclopedia (www.britannica.com, catharsis) as an act of purification and purgation; it is the highest ranks of fear and compassion. In literature, it is treated slightly different in that it is defined as a literary concept which is based on the wording of Aristotle as the fear and pity through the use of metaphoric or embellished language that can teach, reform humans (Childs and Folwer, 2006: 23).

Scheff (2007) argues that through the constant uses of this phenomenon in different fields, it starts diverging; meaning that in each field, it is intended to employ catharsis for the sole purpose that the field investigates. Accordingly, in literature, catharsis is utilized to give the human the opportunity to have knowledge, reformation and most importantly to have restoration after being exhausted by daily life.

Thinking of purifying oneself, people used to gather in a form of stage and audience to expel fear and anxiety in order to change toward the better. Then the theatre comes to be the principal place where catharsis is practiced, as manifested by Frazer (2005) who argues that catharsis can be applied to all human although there is some sociocultural difference but they are the same in essence.

Frazer (ibid) asserts that catharsis only happens when seeing a tragic event that has a moral value, such as the final scene in Dr. Faustus by Cristopher Marlow in which Dr. Faustus - after being deceived by the Mephistopheles - kept weeping wholeheartedly and was full of regret, seeking to repent a restoration.

According to Pelling (2005: 83-102), the tribal societies lack the ability to express the religious matters in a form of written records easily, a matter which led to the emergence of new religious actors who attempt to show the divine aspects through different performances and other gestural codes to convince people. At the end of the performances is to lead to the tragic events in which people reach the highest levels of fear to change their morals. This goes in line with the Husseini sermons, a customary practice, that the Husseini preacher mostly sits on a higher chair specialized for preaching called "minbar" to preach people (AlKhalidi, 2004: 37-8).

As treated sociologically, catharsis can be collective, i.e., a community, having the same mentality, share the same purpose for using catharsis that could be repeated over time in a regular way as the matter with the Husseini tragic event; they are annually commemorated. It could be repeated for a period of time, and under some stage, it becomes a normal practice that needs no catharsis (Rime, 2009: 1931-3).

\section{Catharsis and Cognitive Linguistics}

Linguistically speaking, catharsis is perceived through certain linguistic expressions that have no direct power to affect the audience unless a kind of processing takes place (Vazquez, 2017: 4). This indicates that there are special linguistic expressions that encapsulate the conceptualization of catharsis; referring to Wiezbika (1999: 304) that the 
linguistic items such as cry and weep do not intentionally evoke catharsis, i.e., catharsis is naturally activated as a response (cathartic effect) to a stimulus (linguistic expression) (ibid).

In terms of transferring catharsis, linguistic expressions and other paralinguistic factors can be referred to as the manner in which catharsis is produced (Goldberg, 1995: 153). This assures that certain lexicalized patterns are introduced, especially the schema of causative motion construction which includes syntactic and semantic structures (ibid).

From a stylistic viewpoint, it is imperative to show the importance of the linguistic expressions that affect the interpretations of the text in a way that triggers the reader/listener to be influenced by the text and consequently the theme is delivered (Jeffries, 2010: 126). After being linguistically accessed to the text, catharsis is approached through the mental linguistic enterprise as discussed above in order to express the conceptual stages of catharsis. It is used for thematic purposes in the literary works which have a special focus on social, political, religious issues ... to name but few, based on Lahey (2014:288).

Cognitive stylistics deals with the conceptual processes of how texts (written or spoken) are represented in the human mind and how text producers influence others through such representation (Freeman, 2014: 312).

Three main theories in cognitive linguistics which are related to cognitive stylistics are introduced (ibid). There is the schema theory which means the information stored in the mind regarding any event (Short, 1996: 227); cognitive metaphor theory means that metaphors are conceptually treated as the mapping between the source and the target domain as introduced by Lakoff and Johnsen (1980: 4); text world theory refers to the conceptualization of a text as it is produced to affect the world through a network of worlds which corresponds to the real world discourse (Werth, 1999:284); and deictic shift theory attains that the mere concern to interpret the text is the deictic expression no attention is based on the world (Jeffries, 2010: 157).

To approach catharsis through stages, Vazquez, (2017: 6) states that the event is the basic element on which linguistic choices depend in terms of encoding a certain construction. The choice of linguistic expression for a particular event, on the other hand, is sensitive to culture.

\section{Husseini Preaching}

Of late, Husseini discourse has become one of the topics that deserve to be highlighted in terms of the language used in all associated events. Husseini preaching is of great significance among other events as they try to scientifically introduce the objectives of the Husseini school of thought. This genre has certain features and components that should be followed by the preacher. The Husseini preacher uses certain strategies or qualifications such as utilization of the sound in a special way in order to influence the audience in a pragmatic way (www.ashouraa.almaaref.org ).

The Husseini speech is considered part of the religious sermon, like the Friday sermon and the Eid sermon, but it is believed that the speech of the Husseini sermon needs all what other religious speeches need, maybe more than that. It is a religious sermon as understood, but the area of the speech of the Husseini preaching may be broader than the traditional religious sermon (ibid).

Following Al-Khalidi (2004: 205-234), the Husseini sermon and its discourse has undergone qualitative developments throughout its long history, which began shortly after the martyrdom of Imam Hussein until it reaches the stage in our time, which is considered the finest. The Husseini sermon has several components as follows; catharsis is triggered in one or more of these stages (my italics): 
1. Introduction refers to some utterances which are related to certain conventional sayings regarding the tragedy of Imam Hussein.

2. The poem or Quranic verse is a preliminary stage that can strengthen the sermon, provided that the lines of the poem are relevant to the topic of the sermon. It is recited in tender, melancholic way that leads to provoke the audiences feeling regarding the tragedy. In the last lines, the preacher uses a different intonation contour to have the audience participate with special paralinguistic cues in order to draw the audience's attention.

3. Lecture (research) or (topic) means the subject matter the preacher discusses and that is the most important part: the core of the sermon. Preachers are distinguished among themselves in the area of creativity and explanation that some of them maximize the importance of the subject if dealing with a matter of reality, or draw a comparison between the present day and the tragedy that happened to Imam Hussein, his family members, and his companions.

4. Shifting means to shift from the topic of the sermon to the atmosphere of grief and weeping. The shift should be done in a smooth way that the audience would not feel it. Here, different Husseini preachers use different strategies to shift such as connecting the topic to Husseini events, using special prosodic features and so on. This stage paves the way for the next; it prepares the audience for the calamity of Imam Hussein.

5. The calamity refers to the emotional part of the sermon in which the preacher mentions a tragic event related to Imam Hussein and uses whatever strategies possible to influence the audience emotionally. Again, the skillful Husseini preachers utilize the prosodic factors; they start with a low register and continue with higher and higher to motivate and engage the audience to with them.

6. Supplication is the final part in which the preacher concludes the whole sermon through praying Allah for all the attendants and the believers.

\section{RESEARCH METHODS}

\section{The Cognitive Model of Emotion}

Based on the data to be analyzed, the Cognitive Model of Emotion by Kovecses 2000 for stylistic analysis is adapted to be a workable one; certain parts of the model are not of use for the data, so these parts are eliminated for the sake of redundancy. The model adopts the theory of Text World by Werth 1999. The Cognitive Model of Emotion that is used in this study is divided into five stages:

Cause of emotion $\longrightarrow$ emotion $\longrightarrow$ control $\longrightarrow$ loss of control $\longrightarrow$ behavioral response (Kovecses, 2000: 58)

The first stage of causing refers to the stimuli that lead to the next stage, with the help of the context of the situation. The second stage is where the emotion is provoked to a certain extent in which the emotion is to be controlled in the third stage. Losing the control of the emotion in the fourth stage, the fifth one is responsible to produce the response which is the release of emotion (following the terminology of Kovecses).

\section{Data Collection and Descriptions}

The Husseini discourse is full of practices that are concerned with the religious, social, educational and ideological objectives that Imam Hussein was martyred for along the fourteen past centuries. Most of the objectives are discussed in the sermons presented by 
Husseini preachers, as manifested in section 4 above. Therefore, an unlimited number of sermons and so many preachers pioneered in this regard are found.

To select representative data, taking into account the scope of the current study, four Husseini preachers are selected, based on their religious education background in terms of specialization. Neutrality, transparency, and unbiased preaching are also considered in these four chosen preachers.

Consequently, twenty sermons are to be investigated; each sermon is about fifty to sixty minutes long. These twenty sermons are representative data for analysis. The sermons are taken from the source where they are recorded, and the linguistic parts related to the analysis of the phenomenon in question are transcribed. The following table is the details of the data to be analyzed:

Table 1. Data of the Study with Details

\begin{tabular}{|c|c|c|c|c|}
\hline $\begin{array}{l}\text { Husseini } \\
\text { Preacher }\end{array}$ & $\begin{array}{l}\text { Sayed Jasim Al- } \\
\text { Tuwearjawi }\end{array}$ & $\begin{array}{l}\text { Sheikh Jaffer Al- } \\
\text { Ibrahimi }\end{array}$ & $\begin{array}{l}\text { Sayed } \\
\text { Muhammad Al- } \\
\text { Safi }\end{array}$ & $\begin{array}{l}\text { Sheikh Zaman } \\
\text { Al-Hisnawi }\end{array}$ \\
\hline $\begin{array}{l}\text { Sermon } \\
\text { No. }\end{array}$ & $\begin{array}{l}\text { Sermon Date, } \\
\text { Place \& source }\end{array}$ & $\begin{array}{l}\text { Sermon Date, } \\
\text { Place \& source }\end{array}$ & $\begin{array}{l}\text { Sermon Date, } \\
\text { Place \& source }\end{array}$ & $\begin{array}{l}\text { Sermon Date, } \\
\text { Place \& source }\end{array}$ \\
\hline 1 & $\begin{array}{l}\text { Safar } 7^{\text {th }} 1430 \mathrm{H} . \\
\text { Kut. } \\
\text { TV. }\end{array}$ & $\begin{array}{l}\text { Muharram } 1^{\text {st }} 1440 \\
\text { H. Basrah. Al- } \\
\text { Anwar TV }\end{array}$ & $\begin{array}{l}\text { Muharram } 17^{\text {th }} \\
1440 \text { H. Najaf. Al- } \\
\text { Anwar TV }\end{array}$ & $\begin{array}{l}\text { Muharram } 1^{\text {st }} \\
1440 \text { H. Najaf. } \\
\text { Al-Anwar TV }\end{array}$ \\
\hline 2 & $\begin{array}{l}\text { Muharram } 6^{\text {th }} \\
1433 \text { H. Karbala. } \\
\text { Al-Anwar TV }\end{array}$ & $\begin{array}{l}\text { Muharram } 2^{\text {nd }} \\
1440 \text { H. Basrah. } \\
\text { Al-Anwar TV }\end{array}$ & $\begin{array}{l}\text { Muharram } 21^{\text {st }} \\
1440 \text { H. Najaf. Al- } \\
\text { Anwar TV }\end{array}$ & $\begin{array}{l}\text { Muharram } 4^{\text {th }} \\
1440 \text { H. Najaf. } \\
\text { Al-Anwar TV }\end{array}$ \\
\hline 3 & $\begin{array}{l}\text { Muharram } 7^{\text {th }} \\
1435 \text { H. Basrah. } \\
\text { Al-Furat TV }\end{array}$ & $\begin{array}{l}\text { Muharram } 3^{\text {rd }} 1440 \\
\text { H. Basrah. Al- } \\
\text { Anwar TV }\end{array}$ & $\begin{array}{l}\text { Safer } 1^{\text {st }} 1440 \mathrm{H} . \\
\text { Najaf. } \text { Al-Anwar } \\
\text { TV. }\end{array}$ & $\begin{array}{l}\text { Muharram } 7^{\text {th }} \\
1440 \text { H. Najaf. } \\
\text { Al-Anwar TV }\end{array}$ \\
\hline 4 & $\begin{array}{l}\text { Thulhijjah } 25^{\text {th }} \\
1436 \text { H. Karbala. } \\
\text { Al-Anwar TV }\end{array}$ & $\begin{array}{l}\text { Muharram } 4^{\text {th }} \\
1440 \text { H. Basrah. } \\
\text { Al-Anwar TV }\end{array}$ & $\begin{array}{l}\text { Safer } 14^{\text {th }} 1440 \mathrm{H} . \\
\text { Najaf. Al-Anwar } \\
\text { TV. }\end{array}$ & $\begin{array}{l}\text { Muharram } 9^{\text {th }} \\
1440 \text { H. Najaf. } \\
\text { Al-Anwar TV }\end{array}$ \\
\hline 5 & $\begin{array}{l}\text { Muharram } 6^{\text {th }} \\
1440 \text { H. Karbala. } \\
\text { Al-Anwar TV }\end{array}$ & $\begin{array}{l}\text { Muharram } 14^{\text {th }} \\
1440 \text { H. Basrah. } \\
\text { Al-Anwar TV }\end{array}$ & $\begin{array}{l}\text { Safer } 28^{\text {th }} 1440 \mathrm{H} . \\
\text { Najaf. Al-Anwar } \\
\text { TV. }\end{array}$ & $\begin{array}{l}\text { Muharram } 13^{\text {th }} \\
1440 \text { H. Najaf. } \\
\text { Al-Anwar TV }\end{array}$ \\
\hline
\end{tabular}




\section{RESULTS AND DISCUSSION}

\section{Data Analysis}

The following is a table of the analysis of the Husseini preachers individually.

Table 2. Analysis of the Husseini Preachers Individually

\begin{tabular}{|c|c|c|c|c|c|c|}
\hline \multirow{2}{*}{ No. } & \multirow[b]{2}{*}{$\begin{array}{l}\text { Stage } \\
\text { Hussein } \\
\text { Preacher }\end{array}$} & \multirow[b]{2}{*}{$\begin{array}{l}\text { Cause of } \\
\text { Emotion }\end{array}$} & \multirow[b]{2}{*}{ Emotion } & \multirow[b]{2}{*}{$\begin{array}{l}\text { Control of } \\
\text { Emotion }\end{array}$} & \multirow[b]{2}{*}{$\begin{array}{c}\text { Loss of } \\
\text { Emotion }\end{array}$} & \multirow[b]{2}{*}{$\begin{array}{c}\text { Response } \\
\text { (Release) to } \\
\text { Emotion }\end{array}$} \\
\hline & & & & & & \\
\hline 1. & $\begin{array}{l}\text { Sayed Jasim } \\
\text { Al- } \\
\text { Tuwarjawi }\end{array}$ & $\begin{array}{l}\text { Using poetic } \\
\text { meters, greatly } \\
\text { use of prosodic } \\
\text { features, } \\
\text { whining, using } \\
\text { popular rhymed } \\
\text { poetry with the } \\
\text { inserting of } \\
\text { words as oh } \\
\text { Hussein, } \\
\text { remember } \\
\text { Hussein and } \\
\text { walking done } \\
\text { among the } \\
\text { attendants. }\end{array}$ & $\begin{array}{l}\text { The audience } \\
\text { starts waving } \\
\text { their hands, } \\
\text { whining like } \\
\text { the preacher } \\
\text { and putting } \\
\text { their heads } \\
\text { down preparing } \\
\text { to weep. }\end{array}$ & $\begin{array}{l}\text { After being } \\
\text { motivated for } \\
\text { weeping, the } \\
\text { audience } \\
\text { increases } \\
\text { their sadness } \\
\text { through } \\
\text { shouting oh } \\
\text { Husseinah, } \\
\text { oh Abasah.. }\end{array}$ & $\begin{array}{l}\text { At this point, } \\
\text { the audience } \\
\text { loses their } \\
\text { control } \\
\text { through } \\
\text { weeping and } \\
\text { crying under } \\
\text { the preacher's } \\
\text { whining } \\
\text { voice. }\end{array}$ & $\begin{array}{l}\text { They burst in } \\
\text { weeping, } \\
\text { hitting the } \\
\text { head and } \\
\text { chest in a } \\
\text { way that they } \\
\text { feel the pain } \\
\text { inside of } \\
\text { them. }\end{array}$ \\
\hline 2. & $\begin{array}{l}\text { Sheikh } \\
\text { Jaffer } \\
\text { Ibrahimi }\end{array}$ & $\begin{array}{l}\text { Telling the } \\
\text { audience a } \\
\text { relevant story } \\
\text { with a special } \\
\text { prosodic } \\
\text { contour to } \\
\text { prepare the } \\
\text { audience. }\end{array}$ & $\begin{array}{l}\text { The audience } \\
\text { are attentive } \\
\text { for the story } \\
\text { and putting } \\
\text { their hands on } \\
\text { the face } \\
\text { expecting } \\
\text { something } \\
\text { related to a } \\
\text { Husseini tragic } \\
\text { event. }\end{array}$ & $\begin{array}{l}\text { The audience } \\
\text { makes } \\
\text { connection } \\
\text { between the } \\
\text { story and } \\
\text { Hussein } \\
\text { tragedy, and } \\
\text { they start } \\
\text { moving the } \\
\text { heads, } \\
\text { waving their } \\
\text { hands and } \\
\text { nodding } \\
\text { down their } \\
\text { heads. }\end{array}$ & $\begin{array}{l}\text { The audience } \\
\text { cannot hold } \\
\text { the emotions } \\
\text { that they } \\
\text { increasingly } \\
\text { weep, sighing } \\
\text { with a lot of } \\
\text { whining, } \\
\text { listening to } \\
\text { the words of } \\
\text { the preacher: } \\
\text { oh, Hussein, } \\
\text { Oh Zahra, } \\
\text { Wa zainabah }\end{array}$ & $\begin{array}{l}\text { They reach } \\
\text { the highest } \\
\text { level of } \\
\text { weeping and } \\
\text { responding to } \\
\text { the preacher } \\
\text { uttering } \\
\text { collectively } \\
\text { and loudly } \\
\text { Oh, Hussein, } \\
\text { Oh Zahraa, } \\
\text { with deep } \\
\text { weeping. }\end{array}$ \\
\hline 3. & $\begin{array}{l}\text { Sayed } \\
\text { Muhammad } \\
\text { Al-Safi }\end{array}$ & $\begin{array}{l}\text { Making special } \\
\text { comparisons } \\
\text { between certain } \\
\text { persons and the } \\
\text { greatest tragedy } \\
\text { of Imam } \\
\text { Hussein, using }\end{array}$ & $\begin{array}{l}\text { Reminding and } \\
\text { picturing the } \\
\text { events and the } \\
\text { sorrow of } \\
\text { Imam } \\
\text { Hussein's } \\
\text { tragedy, saying }\end{array}$ & $\begin{array}{l}\text { The preacher } \\
\text { asks the } \\
\text { audience to } \\
\text { communicate } \\
\text { with him, and } \\
\text { the audience } \\
\text { puts the }\end{array}$ & $\begin{array}{l}\text { By increasing } \\
\text { his voice } \\
\text { loudness, } \\
\text { tenderness, } \\
\text { the preacher } \\
\text { provokes the } \\
\text { audience }\end{array}$ & $\begin{array}{l}\text { The audience } \\
\text { burst in } \\
\text { weeping and } \\
\text { crying with } \\
\text { deep sighs } \\
\text { and whining } \\
\text { that indicate }\end{array}$ \\
\hline
\end{tabular}




\begin{tabular}{|l|l|l|l|l|l|l|}
\hline & $\begin{array}{l}\text { prosodic futures } \\
\text { such as low, } \\
\text { soft pitch of } \\
\text { utterances. }\end{array}$ & $\begin{array}{l}\text { "remember } \\
\text { Hussein, } \\
\text { remember } \\
\text { Sukaina, } \\
\text { remember } \\
\text { Abdullah... }\end{array}$ & $\begin{array}{l}\text { hands on the } \\
\text { face and } \\
\text { looks down } \\
\text { as a way to } \\
\text { show sadness. }\end{array}$ & $\begin{array}{l}\text { emotions, and } \\
\text { they lose } \\
\text { control of } \\
\text { their } \\
\text { emotions }\end{array}$ & $\begin{array}{l}\text { deep sorrow } \\
\text { and grief. }\end{array}$ \\
\hline 4. & $\begin{array}{l}\text { Sheikh } \\
\text { Hisnawinabah... }\end{array}$ & $\begin{array}{l}\text { Using weeping- } \\
\text { like prosody, } \\
\text { mentioning a } \\
\text { certain story to } \\
\text { relate it to the } \\
\text { tragedy of } \\
\text { Imam Hussein, } \\
\text { and emphatic } \\
\text { intonation } \\
\text { contours. }\end{array}$ & $\begin{array}{l}\text { The more his } \\
\text { voice gets } \\
\text { tender and } \\
\text { manipulated, } \\
\text { the more the } \\
\text { audience is } \\
\text { ready for the } \\
\text { weeping and } \\
\text { connected with } \\
\text { the preacher. }\end{array}$ & $\begin{array}{l}\text { The } \\
\text { attendants } \\
\text { show that } \\
\text { they are } \\
\text { connected } \\
\text { with the } \\
\text { preacher and } \\
\text { start to wave } \\
\text { with theirs } \\
\text { hands, } \\
\text { nodding their } \\
\text { heads down. }\end{array}$ & $\begin{array}{l}\text { At this point, } \\
\text { they cannot } \\
\text { hold } \\
\text { themselves } \\
\text { they start } \\
\text { whining and } \\
\text { weeping. }\end{array}$ & $\begin{array}{l}\text { Having } \\
\text { reached to the } \\
\text { highest level } \\
\text { of grief and } \\
\text { sorrow, the } \\
\text { audience } \\
\text { keeps } \\
\text { weeping and } \\
\text { weeping with } \\
\text { deep remorse } \\
\text { that they are } \\
\text { ready to do } \\
\text { the right } \\
\text { behavior. }\end{array}$ \\
\hline
\end{tabular}

Now, the overall analysis of the data is to be described in accordance with the following stages of the model:

1. In the cause of emotions stage, the Husseini preacher makes use of prosodic features that indicate weeping, whining tones, melody meters, popular rhymed poetry whose mere aim is motivating people and high register prosodic contour. In the fourth part of the sermon, not only linguistic and paralinguistic cues are used, the Husseini preacher walks down among the audience. There are certain linguistic realizations used by Husseini preachers, along with the paralinguistic cues. Such linguistics relaxations are mentioned within the lamentation. Most of them are related to the Imam's names and titles.

2. The audience's emotions are provoked, and some gestures as putting the hand on the face or nodding the head down - indicating that they are trying to be connected with the situation are produced. They utter certain prosodic contours, i.e., rise-high-fall, in order to be harmonized with the preacher's poetry. In this stage, the audience becomes connected with the preacher's motivating weeping.

3. At the next stage of lamenting, through special use of prosodic factors with a special linguistic expression, especially "Ya Hussein", the audience try to control their emotion. They start hitting their heads and chests with other emotional moves, trying to go along with the situation at the time.

4. Reaching the highest level of tragedy by using extra intonations, whining tones, high pitch levels, mentioning utterances such as Wa Husseinah, Wa Abbasah, Wa Zahraa, Wa zainabah etc. At this stage, the audience lose control of the emotions. Here the audience burst in tears, weeping on the tragedy and all the tragic events that are mentioned with special prosodic contours by the preachers.

5. The behavioral response is through the release of emotions. The audience keep weeping and uttering what the preacher says. The audience starts severe weeping and 
sometimes crying loudly and hitting the heads and the chests with the hands in a staged manner, indicating the fear and tenderness of the attendants' souls. At this point, the audience reache the highest degree of fear and purgation, i.e. catharsis. So doing, the preacher has successfully influenced the audience in such a way that they become very sensitive to learn what the right behaviour to do: following the Husseini teachings.

\section{Discussion}

Based on the description and analysis of the data analyzed above, certain points regarding the data viz Husseini sermons are to be commented on. The four Husseini preachers are all committed to the structure of the religious Husseini sermon. The four parts are well manifested through the content and linguistic utterances used to represent that, though some preachers rely on their own words in dealing with these four parts, as argued by AlKhalidi (2004) in section 4 above.

This leads to the issue of where to find catharsis; in which part of the sermon catharsis is manifested. By definition (Childs and Folwer, 2006: 23; Scheff (2007), catharsis can be found where the audience weep due to grief and sorrow. This is demonstrated mostly in two parts of the sermon; the first and the fifth parts. Certain Husseini preachers may lead the audience to catharsis in the second, third and fourth parts of the sermon as noticed by Sayed Jasim Al-Tuwarjawi and Sayed Muhammad Al-Safi in their analyzed sermons. They do so through mentioning some referents to all those Husseini family members who are involved in the tragedy, utterances like: oh, Hussein, Wa zainabah, oh Sukaina, oh, my father Husseini, oh, the one who was martyred at the water source... etc. All these linguistic terms activate the deep sorrow and grief inside the audience that leads them to catharsis.

Pedagogically speaking, Husseini preachers' teach the audience for all the tenant of Imam Hussein. Their use of the prosodic factors represents the strongest device to draw the attendants' attention to the holiness and greatness of the events. In other words, the Husseini preachers take into account the audience education level in order to follow certain strategies rather than others. Other factors as the place, time type of event and the situation are regarded as key factors in stirring the audience's emotions.

The sermons in the holy month of Muharram are different from other sermons at other times. The event is, on the other hand, plays a confirmable role in leading to catharsis, in the sense that some preachers start the sermons with catharsis and end with it too. This is based on the event per se. Walking down to sit among the audience as Sayed Jasim AlTuwarjawi does in most of the analyzed sermons is a strategy to be in direct contact with the audience. This kind of performance can be highly related to what has been attained by Pelling (2005: 83-102), referring to it as body movements and sound signals to teach people of the divine aspects, especially for those who have low Islamic educational level.

The Husseini preachers' use of the chronological order of the parts of the sermon is in line with the model of analysis, especially the first and fifth parts. These two parts demonstrate the phenomenon in question through the five-stage model as explained in section five.

Leading the audience to catharsis is not an easy task, meaning that this requires the preacher's outstanding ability and skill. This can be accomplished by choosing the right effective linguistic utterances that provoke the audience's catharsis. Therefore, all the audience in the sermon is sad but this does not mean that all of them can be led to catharsis. This is due to the linguistic choice which is completely related to stylistic variations. Choosing the utterances such as: oh, Hussein, oh, Abbas, oh Zahraa, Wa 
zainabah ...etc. all can activate sadness and grief in the audience. However, the way in which they are uttered in terms of prosody, repetition or rhymed lines could provoke the audience's emotions. On the other hand, Husseini preachers cannot use such utterances without preparing the audience nor can they lead their audience to catharsis.

Now that these are the key factors relevant to catharsis, the last stage in the model is responsible for the release of the emotions and more importantly related to the pure part of human being. At this point, after the attendants who have experienced catharsis, they are ready to change themselves for better and keep the events of the tragedy in their minds, as asserted by Vazquez, (2017). Husseini preachers use this strategy for these two purposes respectively; preaching about the Husseini tragedy and cause as well as to educate people on different levels of life.

\section{CONCLUSION}

The study has come up with the following conclusions:

1. Through studying catharsis, it is concluded that the Husseini discourse is a genre that merits attention and investigation at different linguistic levels.

2. Catharsis is a highly employed device in Husseini discourse under its cognitive implications.

3. Husseini preachers pragmatically use prosodic features to convey catharsis.

4. Catharsis is utilized by Husseini preachers as a strategy to teach the audience all the objectives of the Husseini revolution and to connect the objectives to this age for the sake of reform, using the fear that can modulate the human behaviour.

5. Leading the audience to catharsis requires a highly professional preacher with specific voice qualities.

\section{REFERENCES}

Al-khalidi, F. (2004). Al-Minbar Al-Husseini: Evolution, Current Trends and Future Perspectives. Al-Hilal Publications: Beirut.

Childs, P. and Fowler, R. (2006). The Routledge Dictionary of Literary Terms. Routledge: London and New York.

Frazer, J. (2005). Selected Letters of Sir J.G. Frazer (Ackerman R. ed). Oxford: Oxford University Press.

Freeman, M. H. (2014). "Cognitive Poetics". In M. Burke (Ed.), The Routledge Handbook of Stylistics (p. 540). Routledge. Retrieved October 28, 2018, from www.b-ok.org

Goldberg, A. E. (1995). Constructions. A construction grammar approach to argument structure. Chicago: University of Chicago Press.

Jeffries, L., \& Mclntyre, D. (2010). Stylistics. Cambridge University Press.

Kövecses, Z. (2000). Metaphor and emotion. Language, culture, and body in human feeling. Cambridge: Cambridge University Press.

Lahey, E. (2014). "Stylistics and text world theory". In M. Burke (Ed.). Routledge. Retrieved October 28, 2018, from www.b-ok.org

Lakoff, G., \& Johnson, M. (1980). Metaphors we live by. Chicago: The University of Chicago Press.

Pelling, C. (2005). "Tragedy, Rhetoric, and Performance Culture." In Gregory (2005, 83102).

Rimé, Bernard; Páez, Darío; Basabe, Nekane; Martínez, Francisco (2009). "Social sharing of emotion, post-traumatic growth, and emotional climate: Follow-up of Spanish 
citizen's response to the collective trauma of March 11th terrorist attacks in Madrid". European Journal of Social Psychology. 40 (6): 1029-1045.

Scheff T. J. (2007). Catharsis and Other Heresies: A Theory pf Emotion. Journal pf Social Evolutionary and Cultural Psychology. Retrieved in October 28, 2018 from www.bok.org.

Short, M. (1996). Exploring the Language of Poems, Plays and Prose. London and New York: Longman.

Vazquez, M. (2017). Cultural Influence on the Expression of Cathartic Conceptualization in English and Spanish: A Corpus-based Analysis, International Journal of Society Culture and Language. 5(2): 1-14.

Werth, P. (1999). Text worlds: Representing conceptual space in discourse. London: Longman.

Wierzbicka, A. (1999). Emotions across languages and cultures: Diversity and universals. Cambridge: Cambridge University Press.

\section{Web Reference Links}

- http://ashouraa.almaaref.org/pages/taryekh.htm

- http://www.oxfordreference.com/search?q=catharsis\&searchBtn=Search\&isQuickSearch=t rue

- watchfomny.tv/Video/Arabic/alanwar-tv/alanwar-tv.php

- www.youtube.com/channel/UCbAAXu_E5em5gS_sjfq-hFg

- www.youtube.com/watch?v=PyTVLbb69xI 